\title{
Wpływ wiatrowałów na zróżnicowanie cech osadów aluwialnych w dolinach tatrzańskich o różnym stopniu wylesienia
}

\author{
Impact of windthrows on the diversity of alluvial sediment characteristics in the valleys of
} the Tatra Mts. with different degree of deforestation

\section{Anna Michno ${ }^{1 *}$, Katarzyna Wasak' ${ }^{1}$, Mateusz Stolarczyk ${ }^{1}$, Dariusz Strzyżowski ${ }^{1}$, Dominika Wrońska-Wałach'1, Joanna Fidelus², Mateusz Sobucki' ${ }^{1}$, Mirosław Żelazny ${ }^{1}$}

1 Instytut Geografii i Gospodarki Przestrzennej, Uniwersytet Jagielloński, Kraków, * anna.michno@uj.edu.pl

${ }^{2}$ Instytut Geografii, Uniwersytet Pedagogiczny im. KEN w Krakowie

\begin{abstract}
Zarys treści: Celem badań było poznanie zróżnicowania cech teksturalnych oraz cech chemicznych osadów odprowadzonych ze zlewni tatrzańskich objętych wiatrowałem w 2013 roku. Zróżnicowanie to powiązane zostało z energią rzeźby zlewni oraz skutkami wiatrowału. W zlewniach dominowały osady złożone podczas małej dynamiki transportu, jednak dwie zlewnie charakteryzowały się pewnym udziałem (do 10\%) osadów deponowanych w środowisku o większej energii. Jednak zróżnicowanie to związane jest z energią rzeźby badanych zlewni, natomiast wpływ wiatrowałów nie zaznaczył się jeszcze wyraźnie w cechach teksturalnych osadów.
\end{abstract}

Słowa kluczowe: wiatrował, cechy osadów aluwialnych, denudacja, Tatry

Abstract: The aim of the research was to recognize the diversity of the textural and chemical characteristics of the sediments removed from the catchments of the Tatra Mts., which were affected by the windthrow event in 2013. The diversity was related to the morphometry of the catchments and the effects of the windthrow event. In catchments sediments deposited during low transport dynamics dominated, two of the catchments were characterized by some percentage (up to $10 \%$ ) of the sediments deposited in the high-energy environment. However, this diversity is connected to the morphometry of the studied catchments and up to this time impact of the windthrows is not clearly reflected in the textural characteristics of the sediments.

Keywords: windthrow area, aluvial sediment characteristics, denudation, the Tatra Mts.

\section{Wstęp}

Obszary górskie odznaczają się wysoką energią rzeźby wyrażoną dużymi wysokościami względnymi, nachyleniem stoków, rozczłonkowaniem i intensywnością procesów morfogenetycznych. Góry średnie zwykle w całości znajdują się w piętrze leśnym, gdzie pokrywa roślinna pełni funkcje stabilizującą względem zwietrzelin. System stokowy i korytowy funkcjonują zazwyczaj rozłącznie, a do ich kontaktu dochodzi jedynie podczas zdarzeń ekstremalnych i przy udziale antropopresji. Obszary górskie są narażone na działanie zjawisk ekstremalnych, w tym silnego wiatru, którego skutki obejmują zwykle dużą powierzchnię i są czynnikiem zaburzającym funkcjonowanie naturalnych ekosystemów (Clinton, Baker 2000, Ulanova 2000, Šebková i in. 2012). Silne wiatry powodują powstanie wykrotów i zmiany w rzeźbie terenu wskutek saltacji wykrotowej (Gerlach 1960, Kotarba 1970, Schaetzl i in. 1989, Liechty i in. 1997, Rojan 2010, 2012, Pawlik 2012, 2013). Saltacja wykrotowa może odgrywać znaczącą rolę $\mathrm{w}$ denudacji obszaru ze względu na przemieszczenie wraz z systemem korzeniowym materiału mineralnego (do kilkunastu $\mathrm{m}^{3}$ ) (Gabet $i$ in. 2003, Constantine $i$ in. 2012, Pawlik $i$ in. 2013)

W przeciętnych warunkach hydrometeorologicznych $\mathrm{w}$ zlewniach średniogórskich denudacja 
chemiczna dominuje nad denudacją mechaniczną. W średniogórskiej części Tatr Zachodnich przeważa transport materiału rozpuszczonego (92-95\%) nad odprowadzaniem zawiesiny (4-8\%) i materiału wleczonego (0,07-0,26\%) (Krzemień 1991). Okresowy lub lokalny wzrost udziału denudacji mechanicznej związany jest ze zdarzeniami ekstremalnymi lub lokalnymi cechami podłoża geologicznego, a głównym źródłem dostawy materiału mineralnego do koryt są podcięcia erozji bocznej oraz drogi i rynny erozyjne związane z turystyką lub pracami gospodarczymi. Zmiana $\mathrm{w}$ funkcjonowaniu stoków objętych wiatrowałem oraz intensywnymi pracami gospodarczymi powinna być zatem $\mathrm{w}$ dłuższym okresie odzwierciedlona także w cechach osadów mineralnych transportowanych w korycie i odprowadzanych poza zlewnię.

Saltacja wykrotowa jest procesem przyczyniającym się to wzrostu tempa denudacji mechanicznej. Szacuje się, że transport materiału na skutek saltacji wykrotowej jest o rząd wielkości większy niż transport na skutek procesu spełzywania i rząd wielkości mniejszy od transportu powodowanego płytkimi ruchami osuwiskowymi (Gallaway i in. 2009, Pawlik $i$ in. 2013). Badania monitoringowe wykazały, że materiał mineralny $z$ karp denudowany jest stosunkowo wolno (Pawlik 2013), zwłaszcza materiał grubofrakcyjny. Jest to zazwyczaj transport lokalny, gdyż duża część materiału powraca do zagłębienia (Norman $\mathrm{i}$ in. 1995). Niemniej jednak w dłuższej perspektywie czasowej proces ten stanowi składową ogólnego transferu materiału $\mathrm{w}$ obszarach górskich $\mathrm{w}$ rozumieniu Kotarby i Migonia (2010).

Niejednoznaczna jest kwestia dynamiki procesów morfogenetycznych na terenach wiatrowałów. W niektórych obszarach obserwowano wzrost natężenia procesów erozji wodnej i procesów grawitacyjnych (Hasiński 1971, Klementowski 1996, Gerber i in. 2002), zaś w innych - nie obserwowano tego wzrostu (Hancock i in. 2011). W obszarach objętych wiatrowałem stwierdzono również sytuacje zatarasowywania koryt i den dolin, co może prowadziło do wzrostu erozji bocznej i większej dostawy materiału mineralnego do koryta (Lehotský, Greśková 2007).

W analizie skutków przyrodniczych wiatrowałów uwzględnić należy również prace gospodarcze prowadzone na obszarach objętych saltacją wykrotową. Obejmują one usuwanie powalonych drzew, nowe nasadzenia, przy równoczesnym tworzeniu nowej infrastruktury drogowej (Dudziak 1974, Madej 2001, Rojan 2010, Wałdykowski, Krzemień 2013). Prace zrywkowe prowadzone są zazwyczaj przy użyciu ciężkiego sprzętu, który rozcina pokrywy stokowe, a powstające podczas prac drogi stają się głównym źródłem dostawy materiału mineralnego do koryt i den dolin (Krzemień 1991, Madej 2001, Rojan 2009, Rojan i in. 2012). Badania Madej (2001) wskazują, że odprowadzanie materiału ze stoku, w obrębie którego występują drogi zrywkowe, może być nawet 10 razy większe aniżeli w odcinkach zrekultywowanych, gdzie wcześniej istniały szlaki zrywkowe. Podczas opadów oraz roztopów drogi zwiększają gęstość naturalnej sieci hydrograficznej (Froehlich, Słupik 1986, Krzemień 1991), w istotny sposób zmieniają więc obieg energii i materii $\mathrm{w}$ zlewni, wpływając na uruchomienie lub wzrost intensywności współczesnych procesów morfogenetycznych (Laskowski 1996, Wemple i in. 2001, Gorczyca, Krzemień 2010).

Dotychczas nie był badany wpływ wiatrowałów na dynamikę i właściwości bentonicznej materii organicznej (BOM) w dnach potoków. Stwierdzono natomiast, że całkowite wylesienie zlewni będące efektem wycinki drzew wpływa na zmiany BOM poprzez zmniejszenie dostawy liści i fragmentów drewna do potoku, a jednocześnie - zwiększenie dostawy materii organicznej o znacznym stopniu humifikacji na skutek erozji gleby, która następuje przede wszystkim na drogach zwózki drewna (Salo, Cundy 1987, Swank, Crossley 1988, Webster i in. 1990). Ilość BOM w dnie potoku na skutek wylesienia zmniejsza się, przede wszystkim na skutek pogorszenia warunków retencji, które jest efektem zmniejszenia dostawy do potoku pni i gałęzi, które uważane są za najbardziej efektywny czynnik zatrzymujący materię organiczną w potokach górskich (Speaker i in. 1984, Webster i in. 1990, Quinn i in. 2007). Ponadto drzewa sprzyjają stabilizacji linii brzegowej potoków i jej urozmaiceniu, co przyczynia się do zwiększenia retencji BOM w zlewniach leśnych (Speaker i in. 1984).

Występowanie ekstremalnych zjawisk w środowisku może wpływać również na równowagę fosforu w ekosystemach i skutkować zwiększeniem dostawy tego pierwiastka do wód powierzchniowych (Whiters, Jarvie 2008). Związki fosforu zakumulowane $\mathrm{w}$ osadach rzecznych pełnią istotną rolę $\mathrm{w}$ całkowitym obiegu tego pierwiastka $\mathrm{w}$ środowisku przyrodniczym (Jarvie i in. 2005). Do głównych źródeł dostawy fosforu do rzek i potoków zalicza się obecnie erozję gleb oraz brzegów rzecznych (Whiters, Jarvie 2008), opad atmosferyczny (Holtan i in. 1988), użytkowanie rolnicze terenu (Whiters i in. 2003), ścieki komunalne (Neal i in. 2005) oraz przemysł (Mainstone, Paar 2002). Większość fosforu dostającego się do wyżej wymienionych cieków jest skutecznie wiązana w osadach dennych na drodze procesów chemicznych i fizycznych (Jarvie i in. 2005). Skuteczność immobilizacji związków fosforu ma szczególne znaczenie w obniżaniu stężenia tego pierwiastka w ciekach w kontekście eutrofizacji wód (Mainstone, Paar 2002) oraz ogólnego stanu ekosystemów rzecznych.

Celem badań było poznanie zróżnicowania osadów zawiesinowych odprowadzanych ze średniogórskich zlewni tatrzańskich, które objęte zostały wiatrowałem 26 grudnia 2013 r. Przedstawiona została charakterystyka ich uziarnienia oraz wybrane 
cechy chemiczne: zawartość węgla organicznego, azotu oraz fosforu całkowitego. Zróżnicowanie cech osadów powiązano z lokalnymi cechami środowiska przyrodniczego ze szczególnym uwzględnieniem energii rzeźby badanych zlewni, oraz skutkami wiatrowału. Uzyskane wyniki stanowią tło dla poznania denudacyjnych skutków saltacji wykrotowej.

\section{Obszar badań}

Badania prowadzono w czterech zlewniach w Dolinie Kościeliskiej w Tatrach Zachodnich, które objęte zostały wiatrowałem w grudniu 2013 r. Były to zlewnie: Wściekłego Żlebu (WŻ), Krowiego Żlebu (KŻ), Kończystej Turni (KT), oraz Pośredniej Kopki (PK) (ryc. 1). Wysokości bezwzględne w analizowanym obszarze wynoszą od 940 m n.p.m. do 1379 m n.p.m. (tab. 1). Powierzchnia badanych zlewni wynosi odpowiednio: 67,2 ha (WŻ), 25,9 ha (KŻ), 14,1 ha (KT) oraz 13,4 ha (PK). Położone są one głównie $\mathrm{w}$ obrębie jurajskich utworów serii reglowej dolnej (wapieni i margli) oraz utworów triasowych serii reglowej dolnej (dolomitów, wapieni, piaskowców, łupków) (Bac-Moszaszwili i in. 1979). Obszar charakteryzuje się rzeźbą fluwialno-denudacyjną gór średnich (Klimaszewski 1988).

Średnie nachylenia stoków w zlewniach są podobne i wynoszą od $26^{\circ}$ (PK) do $31^{\circ}$ (KT, WŻ). Natomiast procentowy udział klas nachyleń wskazuje na większe zróżnicowanie rzeźby. Znaczna powierzchnia stoków zlewni PK i KT ma nachylenia do $30^{\circ}$. W zlewniach WŻ i KŻ większy udział procentowy mają stoki o nachyleniu powyżej $33^{\circ}$. Procentowy udział nachyleń $30-33^{\circ}$ we wszystkich analizowanych zlewniach jest bardzo podobny. Maksymalne wysokości, deniwelacje i nachylenia $\mathrm{w}$ analizowanych zlewniach mogą wskazywać na podobieństwo pod względem energii rzeźby między zlewniami WŻ i KŻ oraz między zlewniami PK i KT (tab. 1). Zlewnie różnią się $\mathrm{w}$ niewielkim zakresie pod względem rozczłonkowania. Najwyższym stopniem rozczłonkowania charakteryzuje się zlewnia KT, a najmniejszym PK (tab. 1). Warto podkreślić, iż w zlewniach WŻ, PK i KT występują liczne ślady podcięć erozyjnych

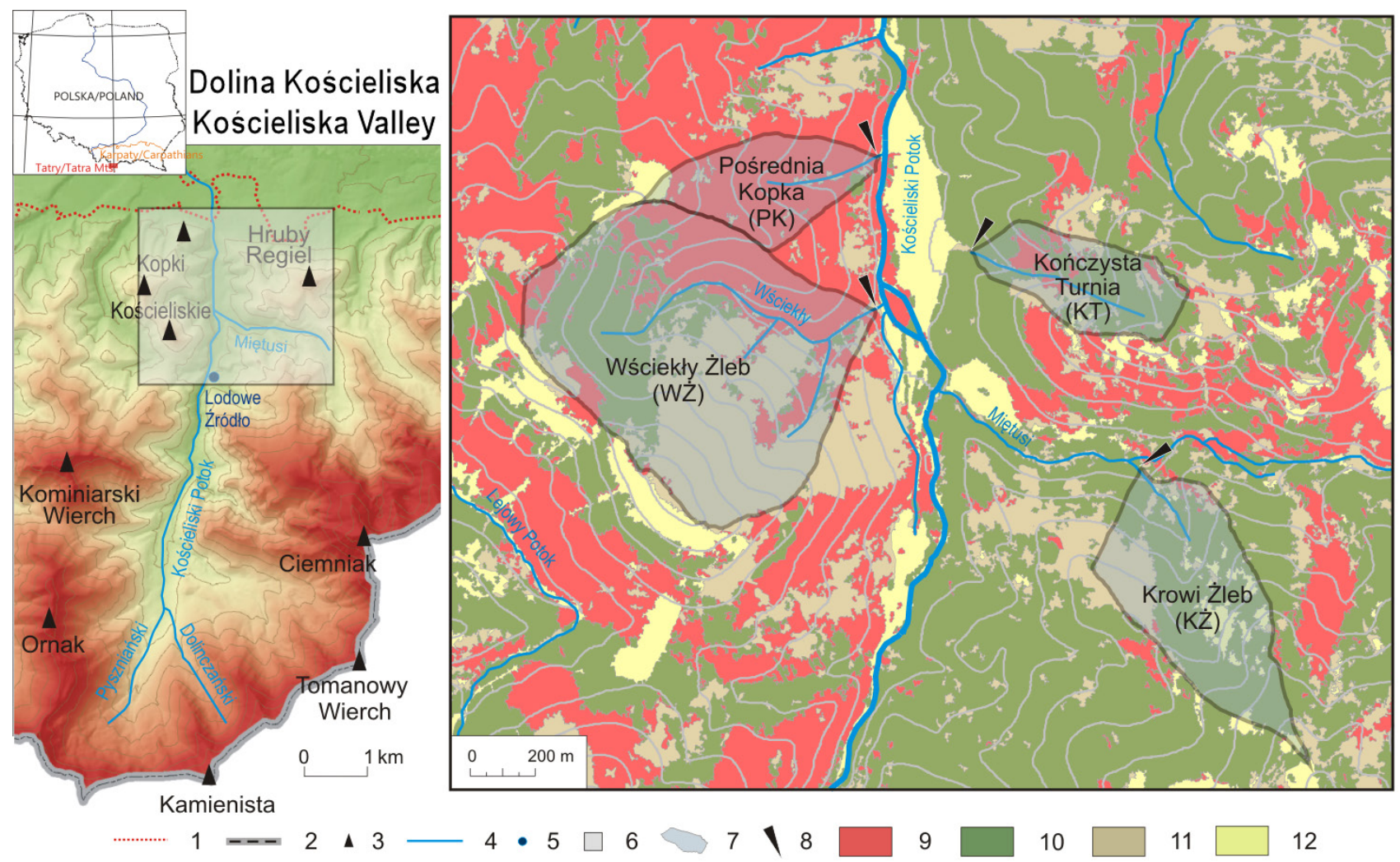

Ryc. 1. Obszar badań

1 - granica Tatrzańskiego Parku Narodowego, 2 - granica państwa, 3 - szczyt, 4 - potok, 5 - wywierzysko, 6 - obszar badań, 7 - granice badanych zlewni, 8 - miejsca poboru osadów, 9 - obszar wylesiony (wiatrował 2013 r.), 10 - obszar zalesiony, 11 - obszar zdegradowanego drzewostanu wskutek gradacji kornika, 12 - łąki; PK - zlewnia Pośredniej Kopki, WŻ - zlewnia Wściekłego Żlebu, KŻ - zlewnia Krowiego Żlebu, KT - zlewnia Kończystej Turni

Fig. 1. Study area

1 - boundary of the Tatra National Park, 2 - state border, 3 - peak, 4 - stream water, 5 - karst spring (vaucluse), 6 - study area, 7 - catchment boundaries, 8 - site of sediment sampling, 9 - area deforested by heavy winds (windthrow) in 2013, 10 - forested area, 11 - area deforested due to tree stand damage caused by the bark beetle, 12 - meadows; PK - catchment of Pośrednia Kopka, WŻ - catchment of Wściekły Żleb, KŻ - catchment of Krowi Żleb, KT - catchment of Kończysta Turnia 
Tabela 1. Parametry morfometryczne zlewni

$\mathrm{H}$ - wysokość bezwzględna, Hsd - odchylenie standardowe, $\Delta \mathrm{H}$ - wysokość względna, L - długość dolin, A - powierzchnia zlewni, D gęstość sieci dolinnej, S - średnie nachylenie zlewni

Table 1. Morphometric parameters of studied catchments

$\mathrm{H}$ - altitude [m a.s.l.], Hsd - standard deviation, $\Delta \mathrm{H}$ - altitude, $\mathrm{L}$ - valley length, A - catchment area, D - valley density, $\mathrm{S}$ - catchment average slope

\begin{tabular}{|c|c|c|c|c|c|c|c|c|c|}
\hline $\begin{array}{l}\text { Zlewnia } \\
\text { Catchment }\end{array}$ & Hmin & $\begin{array}{c}\text { Hmax } \\
{[\mathrm{m} \text { n.p.m.] }}\end{array}$ & Hśr. & $\begin{array}{c}\text { Hsd } \\
{[-]} \\
\end{array}$ & $\Delta \mathrm{H}$ & $\mathrm{L}$ & $\begin{array}{c}\text { A } \\
{[\mathrm{ha}]}\end{array}$ & $\begin{array}{c}\mathrm{D} \\
{\left[\mathrm{km} \cdot \mathrm{km}^{-2}\right]}\end{array}$ & $\begin{array}{c}\mathrm{S} \\
{\left[^{\circ}\right]} \\
\end{array}$ \\
\hline Wściekły Żleb (WŻ) & 953 & 1334 & 1136 & 87 & 381 & 3824,8 & 67,2 & 5,7 & 31 \\
\hline Pośrednia Kopka (PK) & 940 & 1206 & 1065 & 57 & 266 & 603,5 & 13,4 & 4,5 & 26 \\
\hline Kończysta Turnia (KT) & 970 & 1265 & 1115 & 72 & 295 & 953,6 & 14,1 & 6,8 & 31 \\
\hline Krowi Żleb (KŻ) & 996 & 1379 & 1165 & 82 & 383 & 1636,2 & 25,9 & 6,3 & 29 \\
\hline
\end{tabular}

i zerw związane z ekstremalnym zdarzeniem hydro-geomorfologicznym, które miało miejsce w czerwcu 2007 r. (Gorczyca i in. 2014).

Obszar badań zlokalizowany jest w dwóch piętrach klimatycznych: umiarkowanie chłodnym i chłodnym (Hess 1974). Roczne sumy opadów w Tatrach wynoszą od $1200 \mathrm{~mm}$ do ponad $2000 \mathrm{~mm}$ (Niedźwiedź 1992). W okresie badań (VII-XI 2015) opady były niezwykle niskie i w sumie wyniosły 89,7 mm (posterunek opadowy - Wściekły Żleb).

W Tatrach Polskich w dniach 23-26 grudnia 2013 r. wystąpił wiatr o sile huraganu. Największa jego intensywność wystąpiła 25 grudnia, kiedy to średnia prędkość wiatru na Kasprowym Wierchu pomiędzy 18:00 a 22:00 nie spadała poniżej $26 \mathrm{~m} \mathrm{~s}^{-1}$, natomiast najwyższa wynosiła $29 \mathrm{~m} \mathrm{~s}^{-1}$ (dane IMGW). W obrębie Tatr Polskich największe zniszczenia zanotowano w rejonie Kopek Kościeliskich w Dolinie Kościeliskiej (ryc. 2).

Spośród czterech badanych zlewni cząstkowych ekstremalne zniszczenia drzewostanu wystąpiły w zlewni Pośredniej Kopki, gdzie powierzchnia wiatrowału objęła $96 \%$ powierzchni zlewni. W zlewni WŻ, która w dużej mierze była już wylesiona wskutek gradacji kornika, zniszczeniu uległo $25 \%$ powierzchni drzewostanu, głównie na lewym zboczu doliny. W zlewni KT odnotowano zniszczenia w obrębie $10 \%$ powierzchni leśnych, natomiast w zlewni KŻ zniszczenia objęły $5 \%$ powierzchni (dane TPN). W trzech $z$ analizowanych zlewni (PK, WŻ, KT) dominowały drzewostany w wieku od 50 do 150 lat, głównie świerkowe, z niewielkim udziałem jodły (do 10\%). Nieco inaczej wyglądała struktura drzewostanu w obrębie zlewni $\mathrm{KZZ}$, gdzie poza dominującym świerkiem zaznaczał się też duży udział buka (23\%) oraz niewielki udział jodły (8\%), jaworu (5\%) i modrzewia (3\%). Większość drzewostanów w tej zlewni jest w wieku 15-45 lat (Dokumentacja urządzeniowa... 2005).

\section{Metody badań}

Badania terenowe były prowadzone $\mathrm{w}$ okresie wiosna-jesień 2015 roku. Próby osadów do analiz laboratoryjnych pobrano w 4 punktach pomiarowych zlokalizowanych u wylotu badanych zlewni (ryc. 1), w pięciu terminach: wiosna (27.03.), wczesnym latem (10.07.), latem (24.07.), późnym latem (19.08.) oraz jesienią (06.10.). Łącznie do analiz laboratoryjnych pobrano 414 prób osadów aluwialnych o frakcji $<2$ $\mathrm{mm}$. W każdej ze zlewni pobrano osady z lokalnych pułapek akumulacyjnych oraz $z$ dna koryta $w$ strefie nurtu (ryc. 3). Pułapki akumulacyjne stanowiły naturalne tamy zbudowane $z$ drewna lub rumoszu skalnego transportowanego przez płynącą wodę w obrębie koryta potoku.

Dla pobranych prób wykonano analizę uziarnienia, określono zawartość azotu, węgla oraz fosforu całkowitego. Analizę uziarnienia osadów (w przedziałach co 0,5 phi) wykonano metodą sitową (dla osadów $>1$

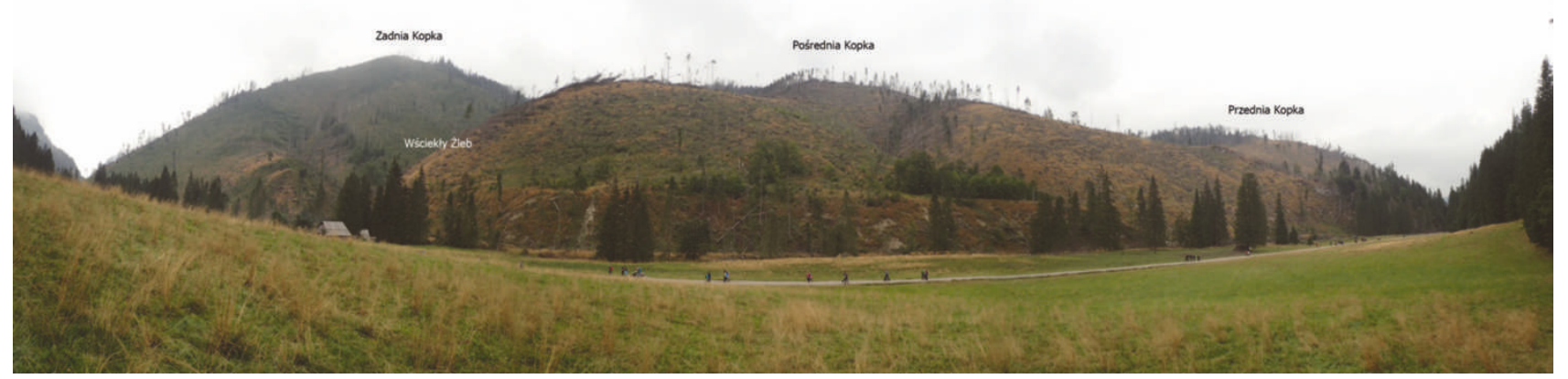

Ryc. 2. Wiatrował w zlewniach Kopek Kościeliskich

Fig. 2. Windthrow site in the catchments of Kościeliskie Kopki 
$\mathrm{mm}$ ) oraz metodą dyfrakcji optycznej w laserowym mierniku cząstek Analysette 22 Comfort (dla osadów $<1 \mathrm{~mm}$ ). Obliczono podstawowe wskaźniki sedymentologiczne (Folk, Ward 1957): średnia średnica ziarn $\left(\mathrm{M}_{\mathrm{z}}\right)$, wysortowanie $\left(\delta_{1}\right)$, skośność $\left(\mathrm{S}_{\mathrm{k}}\right)$, kurtoza $\left(\mathrm{K}_{\mathrm{G}}\right)$. Obliczenia wykonano za pomocą Gradistat 5.11 PL beta. Na tej podstawie określono stopień wysortowania osadów i typ rozkładu uziarnienia. Analiza rozmieszczenia osadów na diagramie $\mathrm{C} / \mathrm{M}$ obrazującym zależność pierwszego percentyla (C) i mediany (M) (Passega 1957, 1964, Passega, Byramjee 1969) posłużyła do zidentyfikowania predyspozycji osadów do transportu w określonym ładunku (trakcja, saltacja, suspensja). Określono też zależność średniej średnicy i odchylenia standardowego.

Całkowitą zawartość węgla (TC) i azotu (TN) oznaczono metodą chromatografii gazowej z użyciem analizatora elementarnego CHNS (Vario Micro Cube). Zawartość węgla nieorganicznego (IC) oznaczono metodą Scheibler'a. Zawartość węgla organicznego (OC) obliczono jako różnicę TC oraz IC. Stosunek węgla do azotu (C/N) oznaczono jako iloraz OC/TN. Fosfor całkowity (TP) wyekstrahowano za pomocą 0,5 M roztworu kwasu siarkowego $\left(\mathrm{H}_{2} \mathrm{SO}_{4}\right)$ na wytrząsarce orbitalnej przez 16 godzin, po uprzednim wyprażeniu osadów $\mathrm{w}$ temperaturze $500^{\circ} \mathrm{C}$ przez 2 godziny (Saunders, Williams 1955 za:
Kuo 1996, Walker, Adams 1958 za: Kuo 1996). Zawartość fosforu całkowitego (TP) oznaczono metodą spektrofotometryczną z użyciem spektrofotometru SPECORD 50 oraz testów na zawartość fosforanów firmy Spectroquant zgodnie $\mathrm{z}$ międzynarodowymi normami EPA 365.2+3, APHA 4500-P E i DIN EN ISO 6878. W charakterystyce chemicznej osadów uwzględniono wartości minimalne, maksymalne oraz medianę.

\section{Zróżnicowanie uziarnienia osadów}

Wściekły Żleb (WŻ). Osady pułapek akumulacyjnych wykształcone są jako mułek piaszczysty, mułek lub piasek mułkowy $\left(\mathrm{M}_{\mathrm{z}}: 3,41-7,65\right.$ phi) i zawierają do $30,4 \%$ piasku grubego $(>500 \mu \mathrm{m})$. Charakteryzuje je bardzo słabe lub słabe wysortowanie $\left(\delta_{1}: 1,68-3,32\right)$ i skrajnie różny rozkład uziarnienia (unimodalny, bimodalny, trimodalny lub polimodalny) (tab. 2). Z wyjątkiem piasku mułkowego osady charakteryzują ujemne wartości skośności, co wskazuje na przewagę w populacji ziarn o większej frakcji niż frakcja o maksymalnej częstości. W 94,2\% są to osady powstające w środowisku o najniższej dynamice - zawiesina jednorodna lub zawiesin typu pelagicznego, $5,8 \%$ osadów zdeponowanych zostało z zawiesiny gradacyjnej

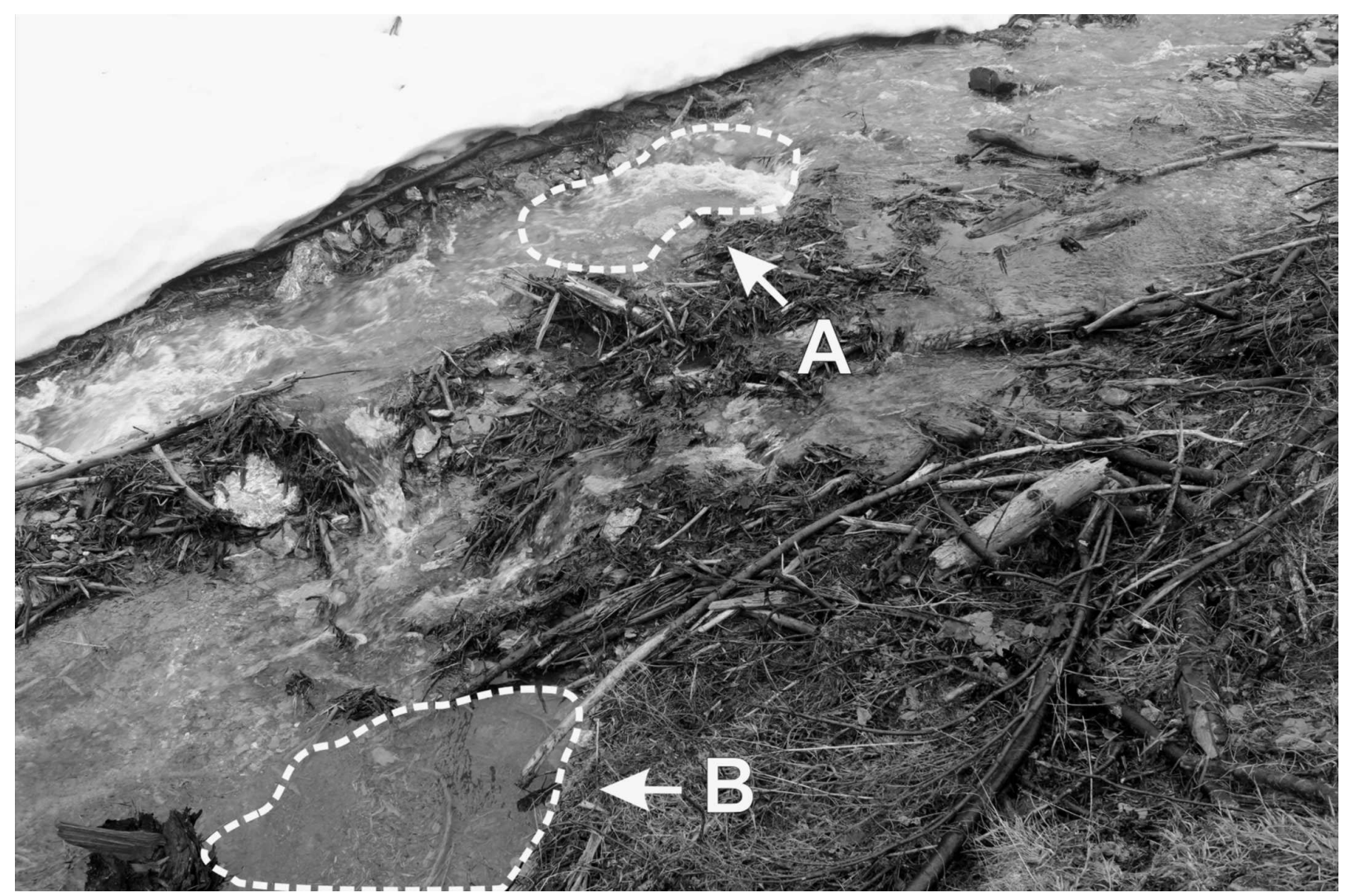

Ryc. 3. Przykład lokalizacji miejsc poboru próbek osadów z nurtu (A) oraz z pułapki akumulacyjnej (B)

Fig. 3. Example site of deposit sampling from stream (A) and accumulation trap (B) 


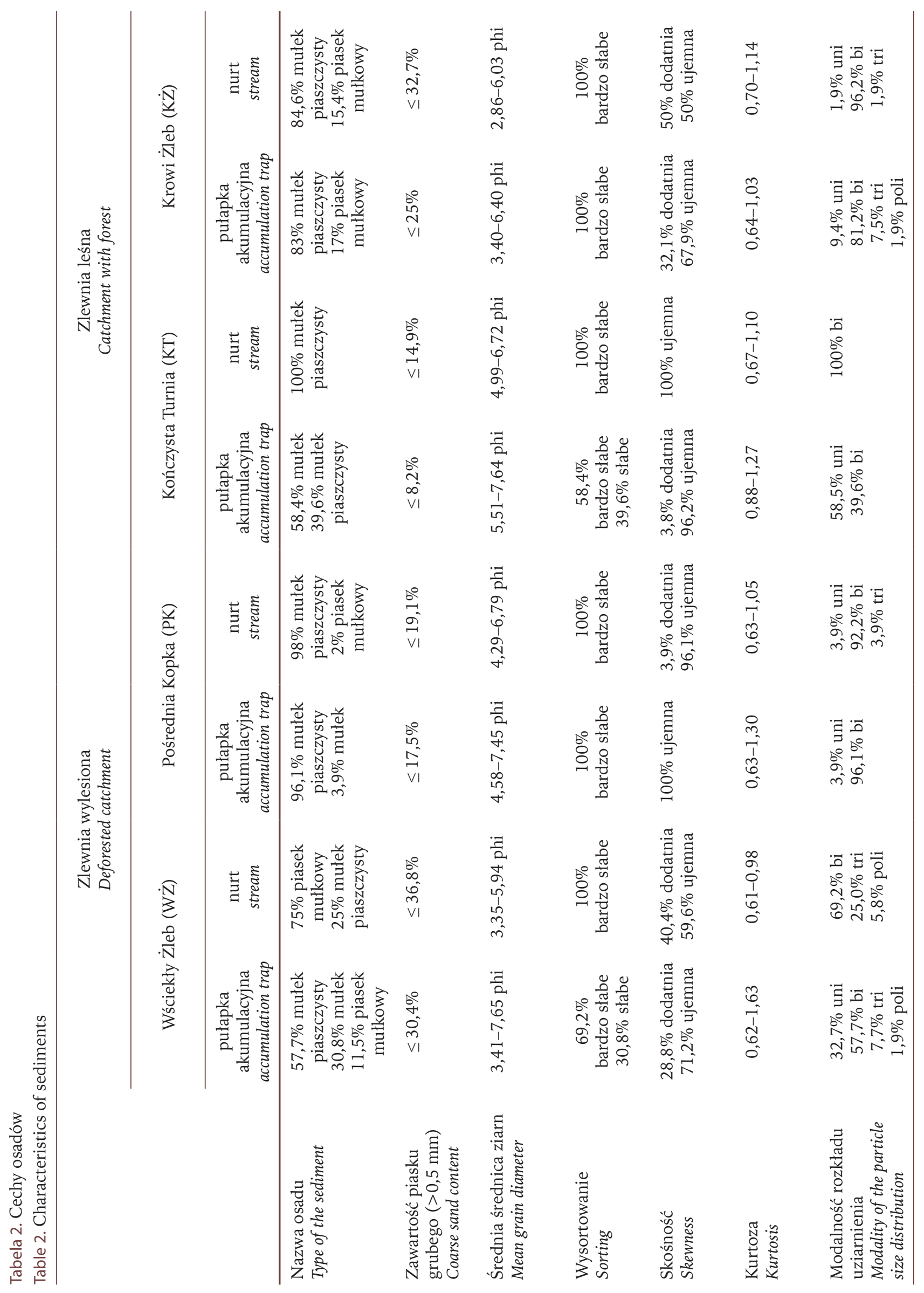


transportowanej w warunkach umiarkowanej lub dużej turbulencji, przy udziale saltacji i trakcji (ryc. 4). Osady pobrane $z$ nurtu (piasek mułkowy, mułek piaszczysty; $\mathrm{M}_{\mathrm{z}}: 3,35-5,94$ phi), zawierają do $36,8 \%$ piasku grubego (tab. 2). Wszystkie osady są bardzo słabo wysortowane $\left(\delta_{1}: 2,84-3,40\right)$, charakteryzuje je zazwyczaj bimodalny rozkład uziarnienia, ale również kilka prób osadów ma rozkład trimodalny lub polimodalny. W $90,4 \%$ są to osady zawiesiny jednorodnej lub zawiesiny typu pelagicznego, 9,6\% to osady zdeponowane z zawiesiny gradacyjnej przy udziale saltacji i trakcji (ryc. 4).

Pośrednia Kopka (PK). Osady pułapek akumulacyjnych w zlewni PK z wyjątkiem dwóch prób (mułek o unimodalnym rozkładzie uziarnienia) wykształcone są jako mułek piaszczysty o bimodalnym rozkładzie uziarnienia $\left(\mathrm{M}_{\mathrm{z}}: 4,58-7,45 \mathrm{phi}\right)$. Osady zawierają do $17,5 \%$ piasku grubego (tab. 2), charakteryzuje je wy- łącznie bardzo słabe wysortowanie $\left(\delta_{1}: 2,01-3,27\right)$, oraz ujemne wartości skośności $\left(S_{\mathrm{k}}\right.$ : $\left.-0,30--0,11\right)$. W całości są to osady powstające w środowisku o najniższej dynamice (ryc. 4). Osady nurtu, z wyjątkiem jednej próby (piasek mułkowy), wykształcone są jako mułek piaszczysty $\left(\mathrm{M}_{\mathrm{z}}\right.$ : 4,29-6,79 phi) zawierający do $19,1 \%$ piasku grubego. Większość osadów cechuje bimodalny rozkład uziarnienia, tylko dwie próby - rozkład unimodalny i trimodalny. Wszystkie osady z wyjątkiem piasku mułkowego charakteryzują ujemne wartości skośności $\left(S_{\mathrm{k}}\right.$ : $\left.-0,29--0,03\right)$. Osady są bardzo słabo wysortowane $\left(\delta_{1}: 2,15-3,35\right)$ i wykazujac predyspozycje do depozycji w środowisku o najniższej dynamice (ryc. 4).

Kończysta Turnia (KT). Osady pułapek akumulacyjnych wykształcone są jako mułek $\left(\mathrm{M}_{\mathrm{z}}: 6,93-7,64 \mathrm{phi}\right)$ lub mułek piaszczysty $\left(\mathrm{M}_{\mathrm{z}}: 5,51-7,64 \mathrm{phi}\right)$. Mułek charakteryzuje zazwyczaj unimodalny, rzadziej bimo-

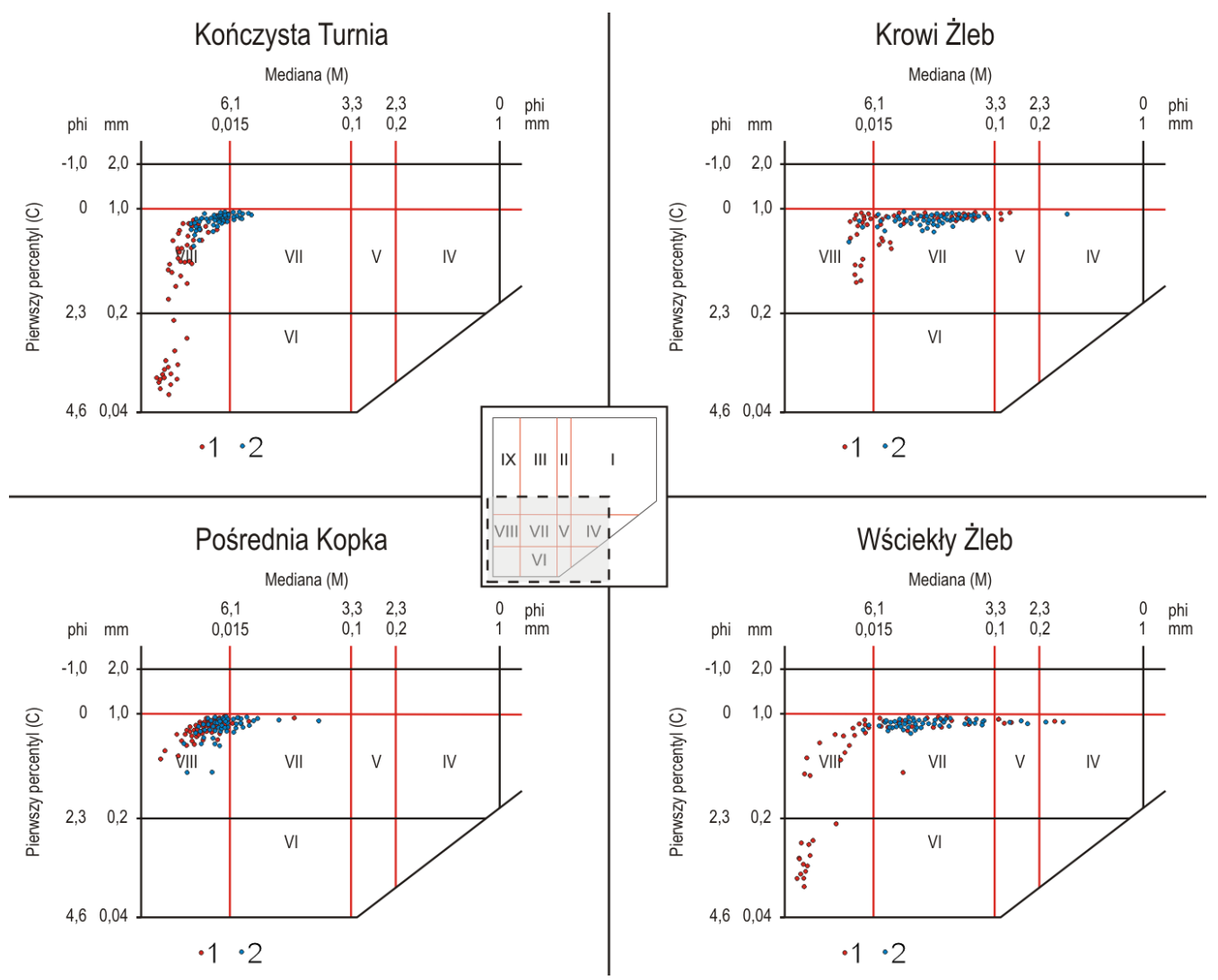

Ryc. 4. Rozmieszczenie osadów $(n=414)$ na diagramie zależności $\mathrm{C} / \mathrm{M}$

Miejsca poboru próbek osadów: 1 - pułapka akumulacyjna, 2 - nurt

Osady: I, II, III, IX - osady transportowane w środowisku o dużej dynamice (trakcja) bez udziału warunków do depozycji materiału z zawiesiny, IV - osady zdeponowane z zawiesiny gradacyjnej transportowanej w warunkach dużej turbulencji oraz saltacji, przy udziale trakcji, $\mathrm{V}$ - osady zdeponowane $z$ zawiesiny gradacyjnej transportowanej w warunkach umiarkowanej turbulencji, VI - osady zdeponowane z zawiesiny gradacyjnej transportowanej w warunkach niskiej turbulencji, VII - osady zawiesiny jednorodnej, VIII - osady powstające $\mathrm{w}$ środowisku o najniższej dynamice, deponowane z drobnoziarnistej zawiesiny jednorodnej oraz zawiesiny typu pelagicznego

Fig. 4. Location of deposits $(n=414)$ on the $C / M$ diagram

Deposit sampling sites: 1 - accumulation trap, 2 - stream current

Deposits: I, II, III, IX - fast-moving sediment (traction) without the right conditions for the deposition of suspended matter, IV - sediment deposited by gradation suspension transported under highly turbulent conditions and saltation, with traction, V - sediments deposited by gradation suspension transported under moderately turbulent conditions, VI - sediment deposited by gradation suspension transported under weakly turbulent conditions, VII - sediment generated by homogeneous suspended matter, VIII - sediment produced under relatively non-turbulent conditions by homogenous fine-grained suspended matter 
dalny rozkład uziarnienia. Są one słabo lub bardzo słabo wysortowane $\left(\delta_{1}: 1,75-2,26\right)$. Natomiast mułek piaszczysty charakteryzuje się nieznacznie większym zróżnicowaniem uziarnienia, zawiera do $8,2 \%$ piasku grubego, charakteryzują się wyłącznie bardzo słabym wysortowaniem $\left(\delta_{1}: 2,26-3,10\right)$ oraz bimodalnym lub unimodalnym rozkładem uziarnienia. W przypadku ponad 96\% osadów skośność przyjmuje wartości ujemne $\left(S_{\mathrm{k}}\right.$ : $\left.-0,01--0,23\right)$ (tab. 2). Wszystkie osady wykazują predyspozycje do transportu w środowisku o najniższej dynamice (ryc. 4). Osady nurtu wykształcone są jako mulek piaszczysty $\left(\mathrm{M}_{\mathrm{z}}: 4,99-6,72 \mathrm{phi}\right)$, są bardzo słabo wysortowane $\left(\delta_{1}: 2,40-3,29\right)$ i charakteryzuje je wyłącznie bimodalny rozkład uziarnienia. Osady te zawierają do $14,9 \%$ piasku grubego (tab. 2). Dla wszystkich osadów charakterystyczne są ujemne wartości skośności $\left(S_{\mathrm{k}}\right.$ : $\left.-0,26--0,13\right)$. Również są to wyłącznie osady deponowane $z$ drobnoziarnistej zawiesiny jednorodnej lub pelagicznej (ryc. 4).

Krowi Żleb (KŻ). Osady pułapek akumulacyjnych wykształcone są jako mułek piaszczysty $\left(\mathrm{M}_{z}: 4,31-6,40\right.$ phi) lub piasek mułkowy $\left(\mathrm{M}_{\mathrm{z}}: 3,40-4,21 \mathrm{phi}\right)$. Są to osady bardzo słabo wysortowane $\left(\delta_{1}: 2,49-3,28\right)$, charakteryzuje je też znaczne zróżnicowanie wartości skośności $\left(\mathrm{S}_{\mathrm{k}}\right.$ : $\left.-0,25-+0,30\right)$ oraz rozkładu uziarnienia (unimodalny, bimodalny, trimodalny lub polimodalny) (tab. 2). Osady zawierają do $25 \%$ ziarn o frakcji piasku grubego. W $94,2 \%$ są to osady zawiesiny jednorodnej lub zawiesiny typu pelagicznego, a w 5,8\% osady zdeponowane z zawiesiny gradacyjnej transportowanej w warunkach umiarkowanej turbulencji (ryc. 4). Osady nurtu wykształcone są jako mułek piaszczysty $\left(\mathrm{M}_{\mathrm{z}}: 4,02-6,03\right.$ phi) lub piasek mułkowy $\left(\mathrm{M}_{\mathrm{z}}: 2,86-3,96 \mathrm{phi}\right)$, zawierają do $32,7 \%$ piasku grubego. Osady charakteryzuje wyłącznie bardzo słabe wysortowanie $\left(\delta_{1}: 2,30-3,01\right)$ i zazwyczaj, z wyjątkiem dwóch prób, bimodalny rozkład uziarnienia. Około $50 \%$ osadów wykazuje ujemne wartości skośności $\left(S_{\mathrm{k}}\right.$ : $\left.-0,19-+0,64\right)$. Większość osadów wykazuje predyspozycję do depozycji w środowisku o najniższej dynamice, tylko w jednej próbie są to osady zdeponowane $\mathrm{w}$ środowisku o wyższej dynamice (ryc. 4).

Najgrubsze osady pułapek akumulacyjnych występują W zlewniach WŻ i KŻ (zawierają do $25-30 \%$ piasku grubego), charakteryzuje je bardzo zróżnicowany rozkład uziarnienia. W większości są to osady deponowane $\mathrm{w}$ środowisku o niskiej dynamice, lecz kilkuprocentowy udział mają również utwory deponowane w środowisku o większej energii. Wyraźnie odróżnia to te osady od utworów pułapek akumulacyjnych w zlewniach PK i KT, gdzie osady w 100\% deponowane były w środowisku o najniższej dynamice. W przypadku osadów nurtu również największym zróżnicowaniem uziarnienia charakteryzują się osady w zlewni WŻ i KŻ (zawierają $>30 \%$ piasku grubego). We wszystkich czterech zlewniach osady nurtu charakteryzuje wyłącznie bardzo słabe wysortowanie. Największym zróżnicowaniem warunków depozycji odznaczają się osady nurtu również w zlewni WŻ (ryc. 4, tab. 2).
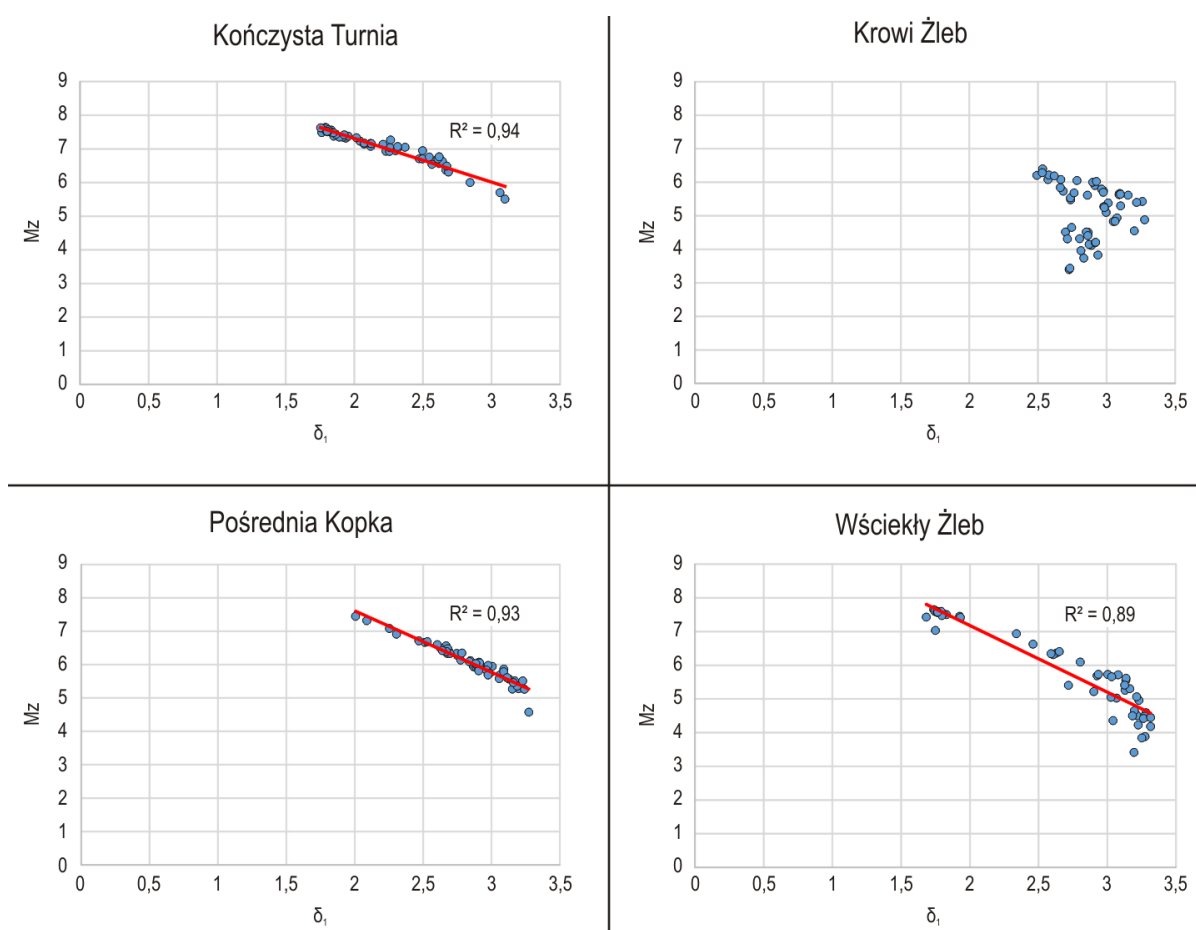

Ryc. 5. Zależność między średnią średnicą ziarn $(\mathrm{Mz})$ a stopniem wysortowania $\left(\delta_{1}\right)$ osadów pobranych z pułapek akumulacyjnych

Fig. 5. Relationship between mean grain size $(\mathrm{Mz})$ and sorting index $\left(\delta_{1}\right)$ of deposits collected from the accumulation traps 


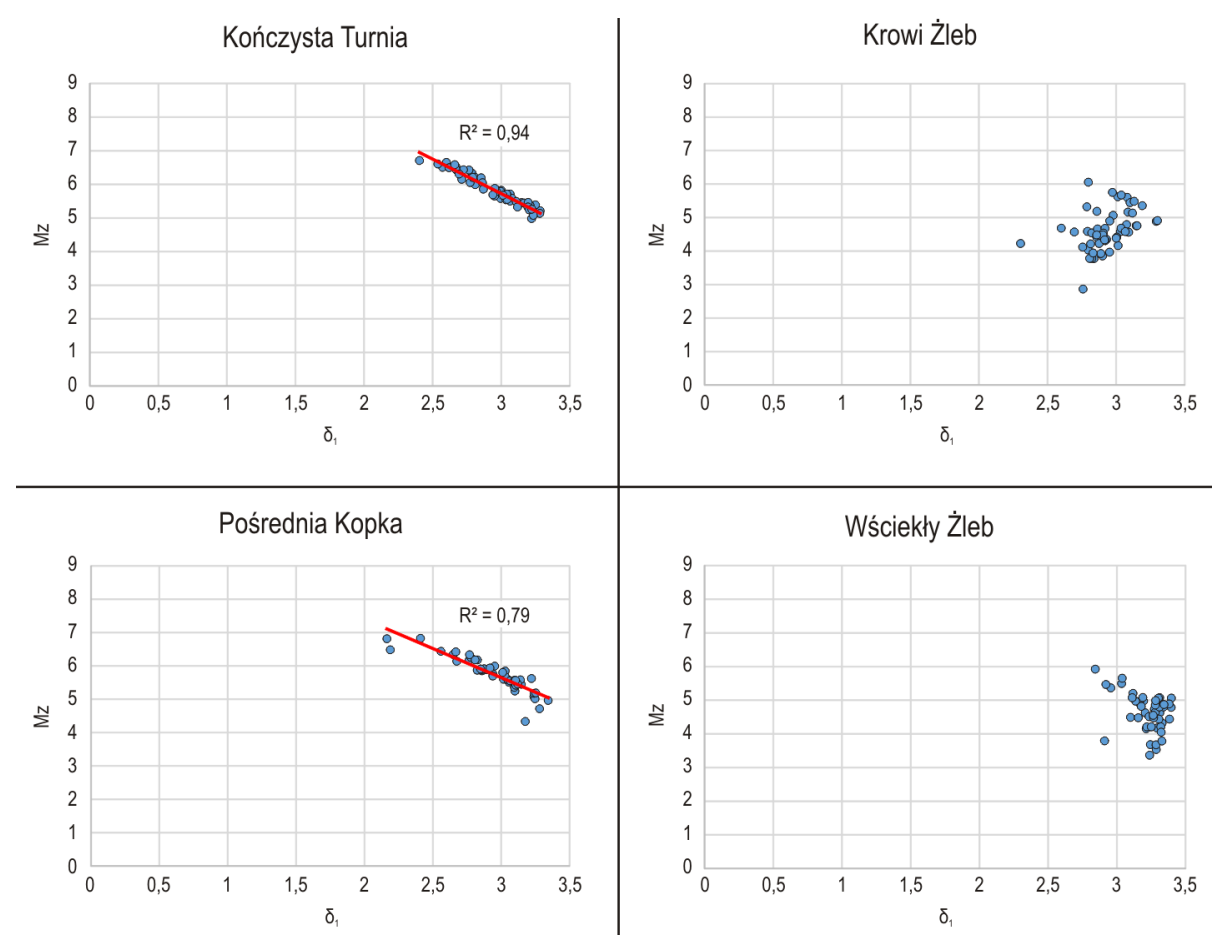

Ryc. 6. Zależność między średnią średnicą ziarn $(\mathrm{Mz})$ a stopniem wysortowania $\left(\delta_{1}\right)$ osadów pobranych z nurtu

Fig. 6. Relationship between mean grain size $(\mathrm{Mz})$ and sorting index $\left(\delta_{1}\right)$ of deposits collected from the stream current

Analiza zależności średniej średnicy ziarn $\left(\mathrm{M}_{\mathrm{z}}\right)$ i odchylenia standardowego $\left(\delta_{1}\right)$ wskazuje, że we wszystkich zlewniach osady pułapek akumulacyjnych są ujemnie skorelowane czyli wzrost średniej średnicy ziaren skutkuje zmniejszaniem stopnia wysortowania osadów (ryc. 5). Jest to układ charakterystyczny dla środowisk o zróżnicowanej dynamice przepływu, w których przeważa sortowanie wcześniej osadzonego materiału i transport poprzez saltację; przedzielają je okresy krótkotrwałego, wzmożonego przepływu, który szybko zmniejszając się powoduje przewagę akumulacji, szczególnie grubszego osadu (układ 1 wg Mycielskiej-Dowgiałło 1995). $\mathrm{W}$ przypadku osadów nurtu $\mathrm{w}$ trzech zlewniach (WŻ, PK, KT) interpretacja zależności jest taka sama jak w przypadku pułapek akumulacyjnych (układ 1). Natomiast $\mathrm{w}$ przypadku osadów nurtu w zlewni KŻ można zauważyć, że wraz ze zmniejszaniem się wartości $\mathrm{M}_{\mathrm{z}}$ zmniejsza się również stopień wysortowania. Jest to trend charakterystyczny dla środowisk o przewadze procesów sortowania w obrębie grubszej frakcji i okresowej dostawie źle wysortowanego materiału transportowanego w zawieszeniu (ryc. 6).

\section{Właściwości chemiczne osadów}

Zawartość węgla organicznego, azotu i fosforu całkowitego w osadach jest większa w materiale pobranym w pułapkach akumulacyjnych niż w nurcie. Koncentracja węgla organicznego jest rzędu od 8,4 do 119,3 $\mathrm{g} \mathrm{kg}^{-1}$ (mediana) w osadach pobranych z pułapek akumulacyjnych (tab. 3) i od 3,4 do $28,4 \mathrm{~g} \mathrm{~kg}^{-1} \mathrm{w}$ osadzie pobranym $z$ nurtu (tab. 4), zaś azotu wynosi od 0,4 do $2,8 \mathrm{~g} \mathrm{~kg}^{-1} \mathrm{w}$ osadach pobranych z pułapek akumulacyjnych i od 0 do $1,3 \mathrm{~g} \mathrm{~kg}^{-1} \mathrm{w}$ osadach pobranych $z$ nurtu. Koncentracja fosforu jest rzędu od 94,5 do $405,8 \mathrm{~g} \mathrm{~kg}^{-1} \mathrm{~W}$ osadach pobranych z pułapek akumulacyjnych i od 72,0 do 124,3 $\mathrm{g} \mathrm{kg}^{-1}$ w osadach nurtu.

Zarówno koncentracja węgla organicznego, jak i azotu oraz fosforu całkowitego w osadach wykazuje sezonową zmienność, która jest szczególnie wyraźna w materiale pobranym z pułapek akumulacyjnych (ryc. 7). Największą zmienność wykazują osady pobrane z potoków WŻ oraz KT. W zlewni WŻ największa koncentracja OC i TN w osadzie występuje wiosną i latem (od marca do lipca). W zlewniach leśnych (KT, KŻ) największa koncentracja OC i TN $\mathrm{w}$ osadzie występuje latem $\mathrm{i}$ jesienią (w zlewni KT od lipca do października, zaś w zlewni KŻ - w sierpniu i październiku).

Koncentracja fosforu w osadach pobranych $z$ dna wszystkich potoków osiąga największe wartości $\mathrm{w}$ okresie lata (II połowa lipca). Latem najwyższe wartości osiąga ona w osadach z potoków WŻ i KT, zaś w późnym latem i jesienią - w zlewniach leśnych (KT, KŻ). W ciągu roku zmienia się charakter materii organicznej w zlewni, o czym świadczy zmiana stosunku $\mathrm{C} / \mathrm{N}$. Wartość stosunku $\mathrm{C} / \mathrm{N}$ wynosi od 4,7 do $26,7 \mathrm{w}$ osadach pobranych z pułapek akumulacyjnych oraz od 4,6 do 33,6 w osadach pobranych $z$ nurtu. Najwyższe wartości przyjmuje wiosną i wczesnym la- 
tem oraz jesienią, a najniższe latem i późnym latem. Sezonowe zmiany stosunku C/N szczególnie wyraźnie zaznaczają się $\mathrm{w}$ osadach pobranych ze zlewni WŻ i KŻ. Wiosną i jesienią stosunek $\mathrm{C} / \mathrm{N}$ w tych osadach przyjmuje wartości $>15$, charakterystyczne dla słabo rozłożonej materii organicznej. Sezonowe wahania stosunku $\mathrm{C} / \mathrm{N}$ są większe w osadach z nurtu, niż z pułapek akumulacyjnych.

Tabela 3. Parametry cech chemicznych osadów pobranych z pułapek akumulacyjnych $\left[\mathrm{g}^{\circ} \mathrm{kg}^{-1}\right]$

Table 3. Chemical characteristics parameters of sediments collected from the accumulation traps $\left[\mathrm{g}^{\mathrm{kg}} \mathrm{k}^{-1}\right]$

\begin{tabular}{|c|c|c|c|c|c|c|c|c|c|c|c|c|}
\hline & \multirow{2}{*}{$\begin{array}{l}\text { Zlewnia } \\
\text { Catchment }\end{array}$} & \multirow{2}{*}{$\begin{array}{l}\text { Data poboru } \\
\text { Sampling date }\end{array}$} & \multicolumn{3}{|c|}{$\mathrm{OC}$} & \multicolumn{3}{|c|}{$\mathrm{TN}$} & \multirow{2}{*}{$\begin{array}{l}\mathrm{C} / \mathrm{N} \\
\text { Med. }\end{array}$} & \multicolumn{3}{|c|}{$\mathrm{TP}$} \\
\hline & & & Med. & Min & Max & Med. & Min & Max & & Med. & Min & Max \\
\hline \multirow{10}{*}{ 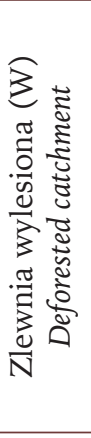 } & \multirow{5}{*}{$\begin{array}{l}\text { Pośrednia Kopka } \\
\text { (PK) }\end{array}$} & 27.03 .2015 & 8,4 & 3,3 & 76,8 & 1,8 & 0,9 & 4,4 & 4,7 & 106,3 & 68,5 & 136,5 \\
\hline & & 10.07.2015 & 34,0 & 10,2 & 42,4 & 2,3 & 0,4 & 2,9 & 16,8 & 124,1 & 95,5 & 175,5 \\
\hline & & 24.07.2015 & 15,8 & 10,9 & 47,9 & 1,7 & 1,3 & 3,2 & 9,6 & 194,5 & 115,5 & 301,0 \\
\hline & & 19.08 .2015 & 20,9 & 9,1 & 47,6 & 1,8 & 0,7 & 3,7 & 14,3 & 97,0 & 63,3 & 133,0 \\
\hline & & 6.10 .2015 & 24,7 & 8,3 & 44,3 & 1,8 & 1,3 & 5,2 & 13,7 & 102,4 & 76,0 & 116,8 \\
\hline & \multirow{5}{*}{$\begin{array}{l}\text { Wściekły Żleb } \\
\text { (WŻ) }\end{array}$} & 27.03 .2015 & 119,3 & 98,8 & 167,7 & 5,2 & 3,7 & 5,8 & 26,7 & 121,8 & 72,8 & 147,8 \\
\hline & & 10.07.2015 & 24,4 & 4,8 & 113,9 & 1,2 & 0,7 & 4,8 & 19,0 & 163,5 & 136,8 & 191,3 \\
\hline & & 24.07 .2015 & 47,5 & 12,8 & 72,4 & 4,0 & 1,5 & 5,3 & 12,1 & 347,0 & 197,3 & 469,0 \\
\hline & & 19.08 .2015 & 13,2 & 1,4 & 26,6 & 1,8 & 1,0 & 4,3 & 7,7 & 97,0 & 72,5 & 146,5 \\
\hline & & 6.10 .2015 & 11,2 & 7,3 & 41,3 & 0,8 & 0,5 & 2,1 & 15,6 & 93,9 & 77,3 & 103,3 \\
\hline \multirow{10}{*}{ 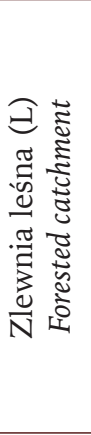 } & \multirow{5}{*}{$\begin{array}{l}\text { Kończysta Turnia } \\
(\mathrm{KT})\end{array}$} & 27.03 .2015 & 38,6 & 35,3 & 57,4 & 2,5 & 2,3 & 3,8 & 15,1 & 213,8 & 197,3 & 226,0 \\
\hline & & 10.07.2015 & 34,3 & 28,3 & 81,3 & 2,9 & 2,8 & 4,9 & 10,3 & 279,3 & 265,8 & 306,5 \\
\hline & & 24.07.2015 & 97,2 & 85,5 & 105,8 & 7,8 & 6,0 & 8,9 & 12,6 & 405,8 & 289,3 & 458,5 \\
\hline & & 19.08 .2015 & 51,0 & 10,4 & 84,0 & 4,1 & 2,3 & 5,3 & 12,8 & 193,0 & 78,5 & 231,5 \\
\hline & & 6.10 .2015 & 29,1 & 11,4 & 76,7 & 5,3 & 1,7 & 7,8 & 9,5 & 230,8 & 183,0 & 374,8 \\
\hline & \multirow{5}{*}{$\begin{array}{l}\text { Krowi Żleb } \\
(\mathrm{KZZ})\end{array}$} & 27.03 .2015 & 37,6 & 35,4 & 57,7 & 1,9 & 1,2 & 3,8 & 19,8 & 159,5 & 78,0 & 189,0 \\
\hline & & 10.07.2015 & 19,6 & 17,5 & 32,4 & 1,1 & 0,8 & 1,9 & 19,6 & 94,5 & 80,5 & 123,8 \\
\hline & & 24.07.2015 & 21,8 & 14,6 & 66,8 & 1,2 & 0,6 & 2,2 & 16,5 & 126,0 & 83,0 & 197,3 \\
\hline & & 19.08 .2015 & 19,8 & 8,1 & 32,6 & 2,3 & 1,0 & 4,1 & 10,4 & 114,3 & 81,5 & 140,5 \\
\hline & & 6.10 .2015 & 56,9 & 42,3 & 76,8 & 3,7 & 2,8 & 5,2 & 16,4 & 191,3 & 153,5 & 228,8 \\
\hline
\end{tabular}

Tabela 4. Parametry cech chemicznych osadów pobranych z nurtu $\left[\mathrm{g}^{\mathrm{kg}} \mathrm{kg}^{-1}\right]$

Table 4. Chemical characteristics parameters of sediments collected from the stream $\left[\mathrm{g} \mathrm{kg}^{-1}\right]$

\begin{tabular}{|c|c|c|c|c|c|c|c|c|c|c|c|c|}
\hline \multirow{2}{*}{\multicolumn{2}{|c|}{$\begin{array}{c}\text { Zlewnia } \\
\text { Catchment }\end{array}$}} & \multirow{2}{*}{$\begin{array}{l}\text { Data poboru } \\
\text { Sampling date }\end{array}$} & \multicolumn{3}{|c|}{$\mathrm{OC}$} & \multicolumn{3}{|c|}{ TN } & \multirow{2}{*}{$\begin{array}{l}\mathrm{C} / \mathrm{N} \\
\text { Med. }\end{array}$} & \multicolumn{3}{|c|}{$\mathrm{TP}$} \\
\hline & & & Med. & Min & Max & Med. & Min & Max & & Med. & Min & Max \\
\hline \multirow{10}{*}{ 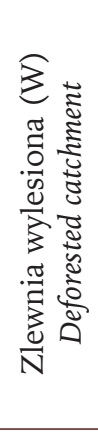 } & \multirow{5}{*}{$\begin{array}{l}\text { Pośrednia Kopka } \\
\text { (PK) }\end{array}$} & 27.03 .2015 & 11,7 & 3,6 & 30,1 & 1,2 & 0,4 & 1,6 & 13,0 & 72,0 & 44,0 & 76,0 \\
\hline & & 10.07.2015 & 14,4 & 9,0 & 20,7 & 1,0 & 0,5 & 1,6 & 12,9 & 114,3 & 105,3 & 141,8 \\
\hline & & 24.07 .2015 & 5,1 & 0,0 & 13,0 & 0,7 & 0,5 & 1,0 & 6,1 & 100,8 & 83,5 & 141,8 \\
\hline & & 19.08 .2015 & 12,2 & 0,4 & 26,0 & 1,1 & 0,0 & 2,0 & 14,1 & 87,9 & 59,8 & 107,8 \\
\hline & & 6.10 .2015 & 3,4 & 0,0 & 38,4 & 0,7 & 0,4 & 2,0 & 4,6 & 94,3 & 80,8 & 99,3 \\
\hline & \multirow{5}{*}{$\begin{array}{l}\text { Wściekły Żleb } \\
\text { (WŻ) }\end{array}$} & 27.03 .2015 & 16,7 & 11,5 & 19,5 & 1,1 & 0,4 & 1,5 & 17,7 & 68,3 & 59,5 & 109,5 \\
\hline & & 10.07 .2015 & 11,7 & 5,7 & 30,3 & 1,2 & 0,4 & 1,6 & 17,5 & 108,0 & 86,3 & 140,8 \\
\hline & & 24.07 .2015 & 6,1 & 0,0 & 18,6 & 0,7 & 0,4 & 1,5 & 8,8 & 99,5 & 53,3 & 122,5 \\
\hline & & 19.08 .2015 & 5,1 & 0,0 & 45,1 & 0,8 & 0,4 & 1,8 & 5,6 & 124,3 & 95,3 & 143,0 \\
\hline & & 6.10 .2015 & 8,4 & 0,0 & 20,2 & 0,5 & 0,2 & 1,6 & 14,7 & 63,6 & 58,8 & 83,0 \\
\hline \multirow{10}{*}{ 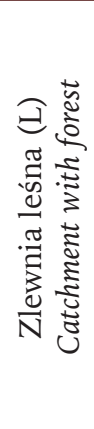 } & \multirow{5}{*}{$\begin{array}{l}\text { Kończysta Turnia } \\
\text { (KT) }\end{array}$} & 27.03 .2015 & 28,4 & 21,4 & 48,4 & 2,4 & 1,4 & 3,3 & 15,3 & 139,3 & 98,8 & 229,5 \\
\hline & & 10.07 .2015 & 22,3 & 13,6 & 31,1 & 1,6 & 1,0 & 1,8 & 13,7 & 141,8 & 108,5 & 158,5 \\
\hline & & 24.07 .2015 & 21,6 & 3,0 & 28,0 & 1,5 & 0,8 & 2,1 & 14,4 & 108,5 & 60,8 & 148,0 \\
\hline & & 19.08 .2015 & 15,4 & 5,1 & 28,6 & 1,3 & 0,6 & 2,3 & 12,3 & 102,0 & 79,0 & 186,8 \\
\hline & & 6.10 .2015 & 14,1 & 0,0 & 21,1 & 1,9 & 1,3 & 2,8 & 7,6 & 136,9 & 124,5 & 149,5 \\
\hline & \multirow{5}{*}{$\begin{array}{l}\text { Krowi Żleb } \\
(\mathrm{KZ})\end{array}$} & 27.03 .2015 & 21,6 & 14,4 & 37,6 & 0,7 & 0,5 & 0,9 & 33,6 & 54,8 & 38,0 & 357,0 \\
\hline & & 10.07.2015 & 20,0 & 12,2 & 33,5 & 0,7 & 0,5 & 2,6 & 24,4 & 116,8 & 57,0 & 131,5 \\
\hline & & 24.07 .2015 & 11,3 & 0,0 & 21,9 & 1,0 & 0,6 & 1,7 & 8,7 & 76,3 & 53,0 & 108,0 \\
\hline & & 19.08 .2015 & 11,7 & 4,8 & 16,2 & 1,0 & 0,6 & 1,8 & 11,0 & 75,8 & 66,8 & 83,5 \\
\hline & & 6.10 .2015 & 16,2 & 7,5 & 24,4 & 1,0 & 0,3 & 1,4 & 15,7 & 83,3 & 69,5 & 91,8 \\
\hline
\end{tabular}



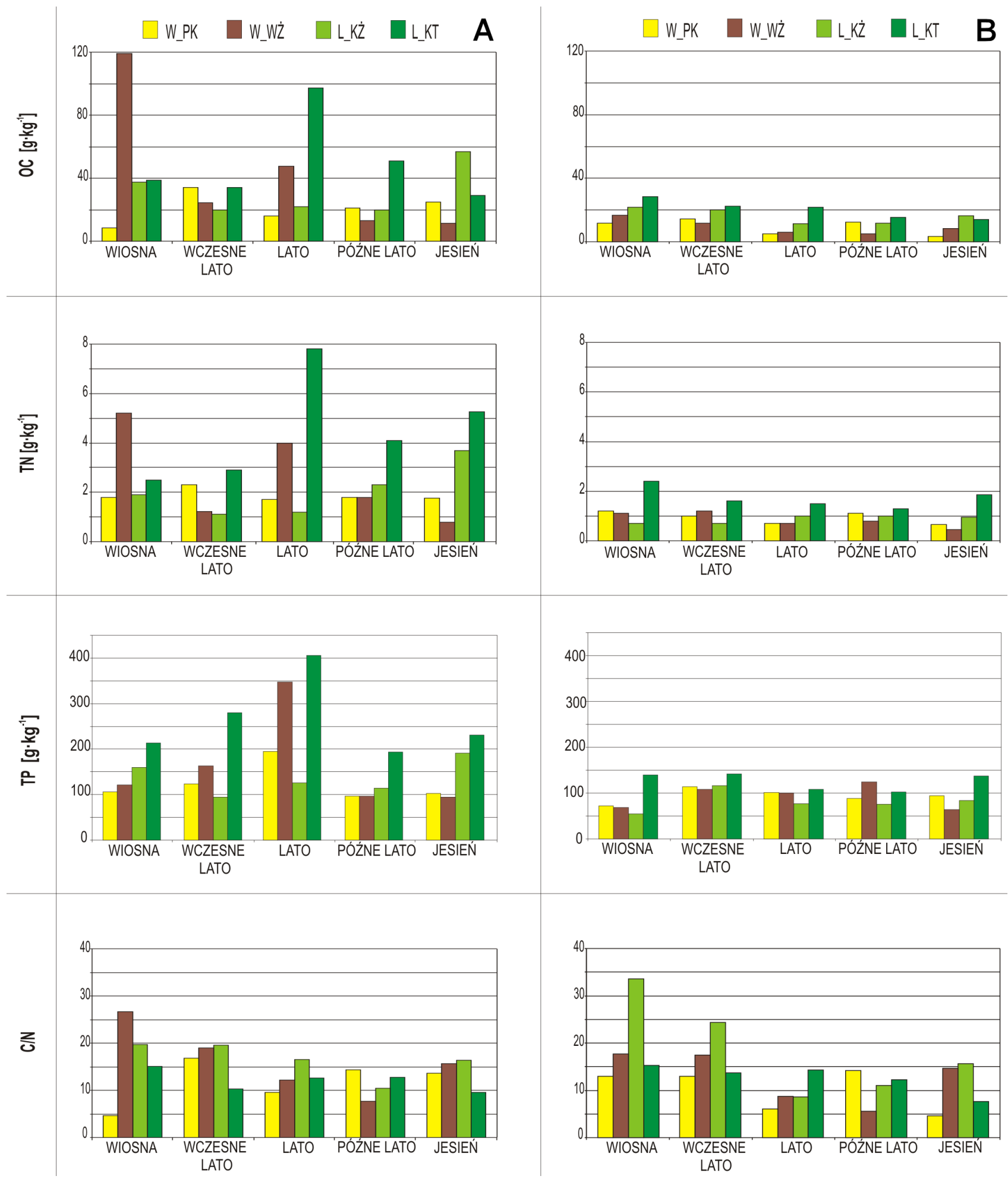

Ryc. 7. Sezonowe zmiany koncentracji węgla organicznego (OC), azotu (TN), fosforu całkowitego (TP) oraz stosunku C/N w osadach z pułapek akumulacyjnych (A) i z nurtu (B): W_PK - zlewnia wylesiona Pośredniej Kopki, W_WŻ - zlewnia wylesiona Wściekłego Żlebu, L_KŻ - zlewnia zalesiona Kröwiego Żlebu, L_KT - zlewnia zalesiona Kończystej Turni

Fig. 7. Seasonal changes in the concentration of organic carbon (OC), nitrogen (TN), total phosphorus (TP) and C/N ratio in deposits from accumulation traps (A) and from stream current (B): W_PK - deforested catchment of Pośrednia Kopka, W_WŻ - deforsted catchment of Wściekły Żleb, L_KŻ - forested catchment of Krowi Żleb, L_KT - forested catchment of Kończysta Turnia; wiosna - spring, wczesne lato - early summer, lato - summer, późne lato - late summer, jesień - autumn 


\section{Dyskusja}

W badaniach dotyczących współczesnej ewolucji rzeźby obszarów górskich należy uwzględnić fakt, że system stokowy reaguje na zdarzenie ekstremalne zazwyczaj z opóźnieniem (Starkel 1996). Przy połączeniu skutków saltacji wykrotowej z geomorfologicznymi rezultatami prac gospodarczych objętość materiału dostarczanego ze stoków do systemu korytowego, zwłaszcza w okresach intensywnych opadów, może być znacząca. Przeprowadzone badania wskazują jednak, że lokalne cechy środowiska, w tym energia rzeźby obszaru, mogą znacząco wpływać na obieg materii w zlewni. Warunkują one gęstość linii spływu podczas opadów oraz cechy teksturalne przemieszczanych osadów. Skutki wiatrowału z 2013 r. oraz prac gospodarczych są wyraźnie zapisane $\mathrm{w}$ zmianie rzeźby stoków, natomiast ich odzwierciedlenie $\mathrm{w}$ cechach osadów odprowadzanych poza zlewnię wymaga dłuższego okresu, sprzyjać temu będą również intensywne opady i roztopy warunkujące transfer osadów pomiędzy stokami a systemem fluwialnym. Warto odnotować, że wywóz drewna $\mathrm{w}$ analizowanych zlewniach był prowadzony przy pomocy lin naziemnych. Taka technika zwózki drewna w praktyce nie naruszała pokrywy zwietrzelinowo-glebowej, co znacząco ograniczyło powstanie nowych rozcięć drogowych i wzrost erozji linijnej.

Cechą odróżniającą zlewnie leśne od zlewni objętych wiatrowałem jest odmienny przebieg koncentracji węgla organicznego, azotu oraz fosforu całkowitego w osadach. Jesienią koncentracja tych pierwiastków $\mathrm{w}$ osadach pochodzących $\mathrm{z}$ pułapek akumulacyjnych jest wyższa w zlewniach zalesionych niż $\mathrm{w}$ wiatrowałowych, co jest zapewne skutkiem dostarczenia do zlewni materiału roślinnego $\mathrm{w}$ postaci opadu głównie igieł świerka, których maksimum opadu przypada jesienią. Wzrost zawartości materii organicznej w osadzie na skutek opadu igieł lub liści jest zjawiskiem charakterystycznym dla zlewni leśnych (King i in. 1987, Delong, Brusven 1993). W zlewniach wylesionych, w szczególności w zlewni Wściekłego Żlebu koncentracja węgla organicznego i azotu w osadzie była najwyższa wiosną. Przyczyną tego zjawiska jest zapewne wzmożony transport materiału organicznego w tym okresie. Natomiast najwyższe zawartości fosforu całkowitego zakumulowanego $\mathrm{w}$ osadach $\mathrm{z}$ pułapek odnotowano latem i późnym latem. Można to tłumaczyć zwiększoną intensywnością prac zrywkowych w tym okresie, które prowadzą do zwiększenia transportu fosforu do wód potoków w zlewniach wylesionych (Whiters i in. 2003, Whiters, Jarvie 2008).

Wysoka wartość stosunku C/N $(26,7)$ w osadzie pobranym z potoku Wściekły Żleb świadczy o tym, że przeważa $\mathrm{w}$ nim słabo rozłożona materia organiczna. Zapewne są to w dużej mierze gałązki i kora, występujące w dużej ilości w obu zlewniach, których powierzchnia została wylesiona wskutek wiatrowału. Wzmożony transport materiału roślinnego w zlewni $\mathrm{KZZ} \mathrm{w}$ porównaniu do PK najprawdopodobniej jest związany z dużą dynamiką środowiska tej zlewni, która wynika $z$ cech morfologicznych zlewni. Cechy te mają wpływ na transport materii organicznej w strumieniu (Delong, Brusven 1993, Vought i in. 1998, Riipinen, Dobson 2010). Wzmożony transport materii organicznej był odnotowany wiosną, w okresie roztopów, kiedy przepływ wody był największy. Istnieją wyniki badań (Naiman, Sedell 1979), które również pokazują, że stosunek $\mathrm{C} / \mathrm{N}$ bentonicznej materii organicznej w potokach górskich zależy od energii rzeźby: $\mathrm{w}$ potokach o większym spadku stosunek $\mathrm{C} / \mathrm{N}$ jest wyższy niż w potokach o mniejszym spadku, co może świadczyć o retencji odmiennego materiału. Nie można całkowicie wykluczyć tego, że zróżnicowanie cech bentonicznej materii organicznej zależy od cech pułapek akumulacyjnych, jednak charakter tych pułapek we wszystkich badanych zlewniach jest podobny.

Również zmiany cech materii organicznej osadów w zlewniach wykazują wyraźny związek z cechami środowiska. W osadach potoków ze zlewni charakteryzujących się większą energią rzeźby (WŻ i KŻ), zaobserwowano wyraźny wzrost stosunku $\mathrm{C} / \mathrm{N}$ w okresie wiosny i jesieni. Może to świadczyć o tym, że w tych zlewniach świeży, słabo rozłożony materiał roślinny był transportowany do dolnych odcinków potoków. Zjawisko to jest szczególnie wyraźne $\mathrm{w}$ osadzie pobranym $\mathrm{z}$ nurtu koryta $\mathrm{w}$ zlewni niemal całkowicie zalesionej (KŻ), gdzie stosunek C/N $\mathrm{w}$ osadzie $\mathrm{z}$ nurtu $\mathrm{w}$ marcu osiąga wartość $>30$ charakterystyczną dla świeżych liści lub ściółek leśnych. Ma to zapewne związek z dostawą świeżego materiału w zlewni leśnej w czasie roztopów. W osadach ze zlewni charakteryzujących się mniejszą energią rzeźby, w tym także zlewni leśnej (PK i KT), stosunek $\mathrm{C} / \mathrm{N}$ jest znacznie niższy $(\sim 15)$ i świadczy o tym, że w osadzie jest deponowany materiał częściowo rozłożony, który może być łatwiej transportowany nawet przy niewielkiej energii płynącej wody (Speaker i in. 1984, Quinn i in. 2007). Wynik ten jest zgodny z wynikami badań Naimana i Sedella (1979). Wykazali oni, że w potokach leśnych zlewni górskich o większym spadku deponowana jest materia organiczna o wyższym stosunku $\mathrm{C} / \mathrm{N}$ niż w potokach o mniejszym spadku, co świadczy o retencji odmiennego materiału roślinnego.

\section{Wnioski}

Największym zróżnicowaniem cech teksturalnych wielkości oraz stopnia wysortowania, charakteryzują się osady pułapek akumulacyjnych i nurtu w zlew- 
niach Wściekłego Żlebu i Krowiego Żlebu. Zlewnie te wykazują podobieństwo w zakresie wysokości, deniwelacji oraz nachylenia. Wskazuje to na duże znaczenie energii rzeźby zlewni dla zróżnicowania osadów aluwialnych i ich obiegu w systemie denudacyjnym. Skutki saltacji wykrotowej związanej z wiatrowałem z grudnia 2013 r. nie zostały jeszcze wyraźnie odzwierciedlone w cechach teksturalnych osadów zgromadzonych w odcinkach ujściowych zlewni. Należy również przypuszczać, że te nastąpią z bardzo dużym opóźnieniem (co być może uniemożliwi ich bezpośrednie powiązanie $z$ wiatrowałem), ponieważ gwałtowna sukcesja roślinności po wiatrowale skutecznie uniemożliwi dalszy transport materiału glebowego.

Właściwości bentonicznej materii organicznej (BOM) w osadach potoków również wykazują związek $z$ energią rzeźby zlewni. W zlewniach o większej energii rzeźby w okresie wiosny, wczesnym latem oraz jesienią następuje akumulacja materii organicznej o mniejszym stopniu rozkładu, co wyraża się wyższym stosunkiem $\mathrm{C} / \mathrm{N}$, niż w zlewniach o mniejszej energii rzeźby. Sugeruje to wzmożony transport i akumulację świeżego opadu roślinnego lub ściółki w tych zlewniach. We właściwościach materii organicznej osadów zostały jednak zidentyfikowane także skutki wiatrowału. Wyrażają się one w odmiennej zmienności sezonowej koncentracji węgla organicznego, azotu oraz fosforu całkowitego $\mathrm{w}$ osadach zlewni leśnych i zlewni objętych wiatrowałem.

Uzyskane wyniki wskazują na potrzebę dalszych badań monitoringowych $\mathrm{w}$ tym obszarze, uwzględniających także prowadzone prace gospodarcze i wielkość zdarzeń hydrometeorologicznych wpływających na okresowe połączenie systemu stokowego i fluwialnego w zlewniach o różnym stopniu pokrycia lasem.

\section{Podziękowania}

Badania zrealizowano w ramach projektu „Ocena wpływu wielkoobszarowych wiatrołomów na reżim hydrochemiczny i denudację zlewni położonych w obszarach leśnych na terenach górskich" (TPN: ZP/371/2015, UJ: K/KDU/000254), sfinansowanego ze środków funduszu leśnego Państwowego Gospodarstwa Leśnego Lasów Państwowych.

\section{Literatura}

Bac-Moszaszwili M., Burchart J., Głazek J., Iwanow A., Jaroszewski W., Kotański Z., Lefeld J., Mastella L., Ozimkowski W., Roniewicz P., Skupiński A., Westwalewicz-Mogilska E., 1979. Mapa geologiczna Tatr Polskich (Geological Map of the Polish Tatra), skala 1:30 000. Wydawnictwo Geologiczne, Warszawa.

Clinton B., Baker C., 2000. Catastrophic windthrow in the southern Appalachians: characteristics of pits and mounds and initial vegetation responses. Forest Ecology and Management 126(1): 51-60.

Constantine J.A., Schelhaas M.J., Gabet E., Mudd S.M., 2012. Limits of windthrow-driven hillslope sediment flux due to varying storm frequency and intensity. Geomorphology 175-176: 66-73.

Delong M.D., Brusven M.A., 1993. Storage and decomposition of particulate organic matter along the longitudinal gradient of an agriculturally-impacted stream. Hydrobiologia 262(2): 77-88.

Dokumentacja urządzeniowa Lasów Skarbu Państwa Tatrzańskiego Parku Narodowego na okres od 1 stycznia 2006 roku do 31 grudnia 2025 roku. Opisy taksacyjne, obwód ochronny Kościeliska, 2005. Przedsiębiorstwo Wielobranżowe Krameko sp. z o.o., Archiwum TPN, Zakopane.

Dudziak J., 1974. Obserwacje nad rozwojem rynien stokowych na polanach tatrzańskich. Czasopismo Geograficzne 45(1): 31-45.

Folk R.L., Ward W.C., 1957. Brazos bar, a study in the significance of grain-size parameters. Journal of Sedimentary Petrology 29: 3-27.

Froehlich W., Słupik J., 1986. Rola dróg w kształtowaniu spływu i erozji w karpackich zlewniach fliszowych. Przegląd Geograficzny $58(1-2): 67-87$.

Gabet E.J., Reichman O.J., Seabloom E.W., 2003. The effect of bioturbation on soil processes and sediment transport. Annual Review of Earth and Planetary Sciences 31: 249-273.

Gallaway J.M., Martin Y.E., Johnson E.A., 2009. Sediment transport due to tree root throw: integrating tree population dynamics, wildfire and geomorphic response. Earth Surface Processes and Landforms 34(9): 1255-1269.

Gerber W., Rickli Ch., Graf F., 2002. Surface erosion in cleared and uncleared mountain windthrow sites. Forest Snow and Landscape Research 77(1-2): 109-116.

Gerlach T., 1960. W sprawie genezy kopczyków ziemnych na Hali Długiej w Gorcach. Przegląd Geograficzny 32(1-2): 86-93.

Gorczyca E., Krzemień K., 2010. Rola dróg i ścieżek turystycznych w modelowaniu rzeźby gór strefy umiarkowanej. Roczniki Bieszczadzkie 18: 228-242.

Gorczyca E., Krzemień K., Wrońska-Wałach D., Boniecki M., 2014. Significance of extreme hydro-geomorphological events in the transformation of mountain valleys (Northern Slopes of the Western Tatra Range, Carpathian Mountains, Poland). Catena 121: 127-141.

Hancock G.R., Evans K.G., McDonnell J., Hopp L., 2011. Ecohydrological controls on soil erosion and landscape evolution. Ecohydrology 5(4): 478-490.

Hasiński W., 1971. Wpływ wiatrołomów karkonoskich na przebieg denudacji. Czasopismo Geograficzne 42(3): 301-303.

Hess M., 1974. Piętra klimatyczne Tatr. Czasopismo Geograficzne 45(1): 75-94.

Holtan H., Kamp-Nielsen L., Stuanes A.O., 1988. Phosphorus in soil, water and sediment: an overview. Hydrobiologia 170: 19-34.

Jarvie H.P., Jürgens M.D., Williams R.J., Neal C., Davies J.J.L., Barrett C., White J., 2005. Role of river bed sediments as sources and sinks of phosphorus across two major eutrophic UK river basins: the Hampshire Avon and Herefordshire Wye. Journal of Hydrology 304(1-4): 51-74.

King J.M., Day J.A., Davies B.R., Henshald-Howard M.P., 1987. Particulate organic matter in a mountain stream in the south-western Cape South Africa. Hydrobiologia 154(1): 165-187.

Klementowski J., 1996. Degradacja pokryw stokowych w warunkach antropopresji. Procesy kriogeniczne, spłukiwanie i erozja żłobinowa. w: A. Jahn, S. Kozłowski, M. Pulina (red.), Masyw Śnieżnika: zmiany w środowisku przyrodniczym, PAE, Warszawa: 121-142.

Klimaszewski M., 1988. Rzeźba Tatr Polskich. PWN, Warszawa.

Kotarba A., 1970. The morphogenetic role of foehn wind in the Tatra Mts. Studia Geomorphologica Carpatho-Balcanica 4: 171188.

Kotarba A., Migoń P., 2010. Góry wysokie a góry średnie Europy - spojrzenie geomorfologa. Czasopismo Geograficzne 81(1-2): $3-19$. 
Krzemień K., 1991. Dynamika wysokogórskiego systemu fluwialnego na przykładzie Tatr Zachodnich. Rozprawy Habilitacyjne UJ 215: 1-160.

Kuo S., 1996. Phosphorus. W: D.L. Sparks (red.), Methods of soil analysis. Part 3, Chemical methods, Soil Science Society of America, Madison: 894-897.

Laskowski L., 1996. Prace zrywkowe a erozja w lasach Gór Sowich. Las Polski 17: 8-9.

Lehotský M., Grešková A., 2007. Morphological response of the high-gradien river to the windblown forest - ecological aspect. Geomorphologia Slovaca et Bohemica 7(2): 79-84.

Liechty H.O., Jurgensen M.F., Mroz G.D., Gale M.R., 1997. Pit and mound topography and its influence on storage of carbon, nitrogen, and organic matter within an old-growth forest. Canadian Journal of Forest Research 27(12): 1992-1997.

Madej M.A., 2001. Erosion and sediment delivery following removal of forest roads. Earth Surface Processes and Landforms 26: 175-190.

Mainstone C.P., Parr W., 2002. Phosphorus in rivers - ecology and management. Science of the Total Environment 282-283: 25-47.

Mycielska-Dowgiałło E., 1995. Wybrane cechy teksturalne osadów i ich wartość interpretacyjna. W: E. Mycielska-Dowgiałło, J. Rutkowski (red.), Badania osadów czwartorzędowych: wybrane metody i interpretacja wyników, Wydział Geografii i Studiów Regionalnych UW, Warszawa: 29-105.

Naiman R.J, Sedell J.R., 1979. Characterization of Particulate Organic Matter Transported by Some Cascade Mountain Streams. Journal of the Fisheries Research Board of Canada 36: 17-31.

Neal C., Jarvie H.P., Neal M., Love A.J., Hill L., Wickham H., 2005. Water quality of treated sewage effluent in a rural area of the upper Thames Basin, southern England, and the impacts of such effluents on riverine phosphorus concentrations. Journal of Hydrology 304(1-4): 103-117.

Niedźwiedź T., 1992. Climate of the Tatra Mountains. Mountain Research and Development 12(2): 131-146.

Norman S.A., Schaetzl R.J., Small T.W., 1995. Effects of slope angle on mass movement by tree uprooting. Geomorphology 14(1): 19-27.

Passega R., 1957. Significance of CM diagrams of sediments deposited by suspension. Sedimentology 24(5): 723-733.

Passega R., 1964. Grain-size representation by CM patterns as a geological tool. Journal of Sedimentary Petrology 34(4): 830847.

Passega R., Byramjee R., 1969. Grain size image of clastic deposits. Sedimentology 13(3-4): 830-847.

Pawlik Ł., 2012. Przekształcenia powierzchni stokowych w Sudetach w wyniku procesu saltacji wykrotowej. Landform Analysis 20: 79-94.

Pawlik Ł., 2013. Implikacje procesu saltacji wykrotowej w biomechanicznym przekształcaniu pokryw stokowych i mikrorzeźby stoku w piętrze regla górnego Karkonoszy Polskich. Prace Geograficzne 135: 41-55.

Pawlik Ł., Migoń P., Owczarek P., Kacprzak A., 2013. Surface processes and interactions with forest vegetation on a steep mudstone slope. Stołowe Mountains, SW Poland, Catena 109: 203-216.

Quinn J.M., Phillips N.R., Parkyn S.M. 2007. Factors influencing retention of coarse particulate organic matter in streams. Earth Surface Processes and Landforms 32(8): 1186-1203.

Riipinen M.P., Dobson M., 2010. Benthic organic matter biomass and invertebrate community structure in five conifer plantation streams in the Peak Distric (Derbyshire, England). Freshwater Forum 28: 61-75.

Rojan E., 2009. Morphological changes within road incision forms in the blowdown area in the Slovak Tatra Mountains after termination of intensive forest works. Landform Analysis 10: 117-123.

Rojan E., 2010. Rola silnych wiatrów w przekształcaniu rzeźby terenu w piętrze leśnym gór, na przykładzie wiatrowału w słowackich Tatrach Wysokich. Czasopismo Geograficzne 81(1-2) 103-123.

Rojan E., 2012. Mikrorzeźba jamowo-kopczykowa w granicach wiatrowału w Słowackich Tatrach Wysokich. Prace i Studia Geograficzne 49: 173-183.

Rojan E., Wałdykowski P., Dąbrowska K., 2012. Wpływ prac leśnych podczas likwidacji szkód poklęskowych na sieć dróg gruntowych na obszarze wiatrowału w Tatrach Słowackich. W: Antropopresja w wybranych strefach morfoklimatycznych - zapis zmian w rzeźbie i osadach, WNoZ UŚ, Sosnowiec: 337-344

Salo E.O., Cundy T.W. (red.), 1987. Streamside management: forestry and fisheries interactions. Collage and Forestry Resources. University of Washington, Seattle, Washington.

Schaetzl R.J., Burns S.F., Johnson D.L., Small T.W., 1989. Tree uprooting: review of impacts on forest ecology. Vegetatio 79(3): $165-176$.

Šebková B., Šamonil P., Valtera M., Adam D., Janík D., 2012. Interaction between tree species populations and windthrow dynamics in natural beech-dominated forest. Czech Republic, Forest Ecology and Management 280: 9-19.

Speaker R., Moore K., Gregory S., 1984. Analysis of the processes of retention of organic matter in stream ecosystems. Verhandlungen des Internationalen Verein Limnologie 22: 1835-1841.

Starkel L., 1996. Geomorphic role of extreme rainfalls in the Polish Carpathians. Studia Geomorphologica Carpatho-Balcanica 30: 21-38.

Swank W.T., Crossley jr. D.A. (red.), 1988. Forest hydrology and ecology of Coweeta. Springer-Verlang, New York.

Ulanova N.G., 2000. The effects of windthrow on forests at different spatial scale: a Review. Forest Ecology and Management 135(1-3): 155-167.

Vought L.B.M., Kullberg K., Petersen R.C., 1998. Effect of riparian structure, temperature and channel morphometry on detritus processing in channelized and natural woodland streams in southern Sweden. Aquatic Conservation: Marine and Freshwater Ecosystems 8(2): 273-285.

Wałdykowski P., Krzemień K., 2013. The role of road and footpath networks in shaping the relief of middle mountains on the example of the Gorce Mountains (Poland). Zeitschrift für Geomorphologie 57(4): 429-470.

Webster J.R., Golladay S.W., Benfield E.F., D’Angelo D.J., Peters G.T., 1990. Effects of forest disturbance on particulate organic matter budgets of small streams. Journal of the North American Benthological Society 9(2): 120-140.

Wemple C.B., Swanson F.J., Jones J.A., 2001. Forest roads and geomorphic process interactions. Cascade Range. Oregon, Earth Surface Processes and Landforms 26(2): 191-204.

Whiters P.J.A., Jarvie H.P., 2008. Delivery and cycling of phosphorus in rivers: a review. Scenice of the Total Environment 400(13): 379-395

Withers P.J.A., Ulén B., Stamm C., Bechmann M., 2003. Incidental phosphorus loss - is it significant and can it be predicted? Journal of Plant Nutrition and Soil Science 166(4): 459-468. 